IFN Working Paper No. 974, 2013

\title{
The Role of Language in Corporate Governance: The Case of Board Internationalization
}

Rebecca Piekkari, Lars Oxelheim and Trond Randøy 


\author{
Rebecca Piekkari (corresponding author) \\ Aalto University, School of Business \\ Department of Management and International Business \\ P.O. Box 21210 \\ FI-00076 Aalto, Finland \\ email: rebecca.piekkari@aalto.fi \\ telephone: +358503837380 \\ Lars Oxelheim \\ Research Institute of Industrial Economics \\ P.O. Box 66665 \\ SE-10215 Stockholm, Sweden \\ email: lars.oxelheim@ifn.se \\ telephone: +4686654527 \\ Trond Randøy \\ University of Agder \\ School of Management \\ Department of Economics and Business Administration \\ P.O. Box 422 \\ NO-4604 Kristiansand, Norway \\ email: trond.randoy@uia.no \\ telephone: +47-38-14 1525
}




\title{
On the role of language in the internationalization of corporate boards
}

\begin{abstract}
Multinational corporations internationalize their corporate boardrooms in order to capitalize on their commercial and financial internationalization. Board internationalization provides access to specialized knowledge and skills, broadens social networks and ensures greater transparency of strategic decision-making. The entry of a foreign board member is often coupled with a change in the working language of the board. The purpose of the present study is to explore and explain how increased language diversity influences decision-making and work processes of corporate boards. We draw on previous research on board internationalization, diversity and language in multinational corporations. Based on a multiple case study of nine multinational corporations from four Nordic countries, we find evidence of impoverished and silenced discussions in board meetings in those case companies that were unprepared to switch to English as the new working language of the board. Some board members found it difficult to contribute to board meetings, articulate disagreement and felt socially excluded from the board. Such effects on decisionmaking and work processes were not found in the well-prepared companies. The study adds to the understanding of different modes to internationalize the board as a response to different forms of internationalization of the firm.
\end{abstract}




\section{ON THE ROLE OF LANGUAGE IN THE INTERNATIONALIZATION OF \\ CORPORATE BOARDS}

\section{INTRODUCTION}

Percy Barnevik, the former long-time CEO of the Swiss-Swedish firm ABB and one of the most influential and well-known business leaders in Europe, notes that in the early 2000s "some Swedish multinationals still had only Swedes on their corporate boards despite reaching figures of 95 percent foreign sales and 80-90 percent foreign production” (Barnevik, 2011, p. 331). In his biography Barnevik highlights the need for internationalizing the Swedish boards and changing their working language to English in order to attract top foreign talent to these boards. Furthermore, he writes that the use of a simultaneous translation service is "the worst option" because it obstructs boards' decision-making (2011, p. 331). Barnevik's experiences suggest that the language used in board meetings is critical to good decision-making in multinational corporations. In the present study, we address this international management issue, which has been ignored in past research, by providing theoretical and empirical understanding of how language diversity affects boards' decision-making.

The starting point of our study is the observation that many firms benefit from diversifying their activities across countries and language environments. The advantages of multinationality are derived from accessing new customers, better supplies, or cheaper funding (Dunning and Lundan, 2008). Multinationality may lead to improved accounting performance but does not ensure higher returns to the firms' shareholders per se. In fact, Filatotchev et al. (2006) argue that without 'good corporate governance" this potential for superior shareholder returns could be wasted. A commonly recognized way to improve corporate governance is through the recruitment of a highly 
competent and appropriately incentivized board (Fama and Jensen, 1983; Filatotchev and Wright, 2011).

Past research suggests that foreign board members are beneficial to firms with significant international activities (Masulis et al., 2012; Oxelheim and Randøy, 2003). Recent research has identified two main motives behind board internationalization, namely the firm's commercial internationalization, such as sales and production abroad, and its financial internationalization, such as accessing funds abroad and listing at foreign stock exchanges (Oxelheim et al., 2013). Oxelheim et al. conclude that in order to enhance financial internationalization, non-AngloAmerican firms prefer to recruit foreign board members, particularly Anglo-American members. In contrast, firms with a high degree of commercial internationalization, but a lower degree of financial internationalization, tend to favour boards that combine foreign and national board members who have experience of relevant foreign markets. Our study provides empirical insights from non-Anglo-American multinationals on how increased language diversity influences decision-making and work processes in corporate boards with foreign members. We concur with Delios (2011, p. 458) that the multinational corporation resembles an "organizational laboratory in which various forms of organizational governance experiments are taking place" (see, also Roth and Kostova, 2003). Our qualitative case study of language diversity in corporate boards of nine multinational corporations offers such a laboratory.

Our main contribution lies in three interrelated areas of research: (1) board internationalization, (2) diversity research, and (3) language in multinational corporations. Firstly, past research on board internationalization has mostly focused on who the foreign members are (Oxelheim et. al, 2013) rather than what they do. However, we would argue that observing the mere presence of foreign board members provides limited insights into how such members affect board behaviour and work processes. We therefore focus on board processes, as suggested by Forbes and Milliken (1999), and find that board dynamics change when a foreign member enters 
the board. While some "domestic" board members felt less capable of expressing their opinion when foreign members were added, others benefited and took the lead in board meetings. We demonstrate that the two case companies that were unprepared for the increased language diversity upon the entry of foreign members, suffered from a lower quality and depth of conversations in board meetings relative to their well-prepared counterparts. In the unprepared group, the board turned into a much more silent decision-making body, which we suggest could have far-reaching effects on board effectiveness. Such deterioration in board meeting interaction was not found among the five companies that were well-prepared for the increased language diversity of the board, nor the two outliers which developed hybrid language solutions. Our analysis of language diversity offers one explanation for why board internationalization may be a slow process.

Secondly, increased board internationalization means greater board diversity. Our study contributes to diversity research by extending it to language as a distinct dimension of diversity, alongside culture and nationality (see, Stahl et al., 2010 for a meta-analysis). The existing diversity literature is primarily concerned with the diversity-performance link, and focuses less on the intervening processes that connect diversity as an input with performance as an output (van Knippenberg and Schippers, 2007; van Dijk et al., 2012). Our study redresses this imbalance by placing board processes and context (Joshi and Roh, 2009) at the centre of attention.

Thirdly, international business research has highlighted the relevance of language issues in multinational corporations (Marschan et al., 1997; Marschan-Piekkari et al., 1999a; 1999b, Neeley, 2013; Peltokorpi and Vaara, 2012; Vaara et al., 2005). These studies suggest that language diversity permeates international management processes, including control and coordination of foreign subsidiaries (Björkman and Piekkari, 2009; Marschan-Piekkari et al., 1999a; 1999b), knowledge sharing and transfer (Mäkelä et al., 2007; Welch and Welch, 2008), as well as cohesion (Barner-Rasmussen and Björkman, 2007) within the multinational corporation. 
However, the implications of these studies for company performance remain elusive. Moreover, the focus on teams as a level of analysis is rare in international business research (see, Kassis Henderson, 2005 for an exception). We view corporate boards as strategic decision-making teams, thus offering insights into how board diversity might affect performance.

Our paper is structured in five parts. We first review past research on board internationalization, diversity in work groups, and language in multinational corporations. Insights from these three streams of research are then integrated when discussing the role of communication and shared language in board processes. Thereafter, we discuss the choice of our case-based research strategy and provide the reader with an overview of the Nordic region as a research context. Our findings reveal an increase in language diversity in the nine case companies after the entry of the first foreign board member. The effects of language diversity on decisionmaking and work processes of the board are then contrasted and compared between the wellprepared, the unprepared and the outlier cases. The discussion part visualizes our key findings and positions them in the extant literature. In the conclusion we argue why the topic is both timely and important and acknowledges the limitations of our study.

\section{LITERATURE REVIEW}

In order to provide a sound theoretical background for the study of language diversity and board internationalization, we review research from the areas of board internationalization, diversity research, and language issues in multinational corporations. We capitalize on the insights from these strands of literature in our discussion of the role of communication and shared language in board processes. 


\subsection{Research on board internationalization}

When addressing corporate board decision-making, it is necessary to acknowledge that such decisions take place in the context of a particular corporate governance system, and that these systems differ extensively around the world (e.g., Denis and McConnell, 2003; La Porta et al., 1999). For example, research on venture funded firms suggests that U.S. boards are much more involved in making corporate governance decisions, such as CEO hiring and firing, than European boards (Bonini et al., 2012).

Although corporate governance systems are rather stable over time within the same country, internationalizing firms can modify their corporate governance and capture elements from foreign corporate governance systems by including foreign board members or internationally experienced national board members (Oxelheim and Randøy, 2013; Sanders and Carpenter, 1998). The advantage of having foreign board members is that they may be more competent at assessing firm performance and prospects in foreign markets than home country nationals; they may contribute by networking with global suppliers, buyers and providers of finance and ensure the transparency of strategic decisions and the accountability of the firm's actions beyond the national context, thereby securing international legitimacy and resource access (Luo, 2005). Foreign board members might also enhance external communications when reaching out to foreign investors and regulators.

Previous research shows that the internationalization of the board is a slow process, or even one of the last steps in the firm's internationalization process (Oxelheim et al., 2013). Some of the reasons for slow internationalization of the board are institutional, e.g., the largest owners are commonly based in the home country and the nomination committees are often recruited among these owners. Other reasons are firm-based, e.g., due to inertia the present board is not prepared to have its existing practices changed by the inclusion of a foreign board member. 
The slow recruitment of female directors in Nordic firms is another example of the 'old boy's network' type of boards' resistance to change. Our study offers language diversity as another reason for the slow internationalization of corporate boards.

Previous research on corporate boards in general has concentrated on uncovering the motives behind board composition, and its impact on performance (e.g., Daily et al., 2003). In this regard, considerably less effort has been devoted to understanding how board processes work (Pettigrew, 1992), and how diverse board members such as women (for an exception, see Nielsen and Huse, 2010), and foreigners affect the actual behaviour of boards as decision-making bodies. Thus, we specifically seek to address the linkage between board internationalization, diversity and board processes in terms of language diversity.

\subsection{Diversity research}

The internationalization of corporate boards brings to the fore various dimensions of diversity such as culture, nationality, ethnicity and language. Existing board research typically refers to these attributes as aspects of board "demography" (e.g., Miller and Triana, 2009) rather than "diversity" which is a commonly used term in research on work groups and teams. Given the limited amount of previous research on diversity in corporate boards, we capitalize on the broader work group and team literature. In their extensive review of previous research on work group diversity, van Knippenberg and Schippers (2007. p. 517) define diversity as "differences between individuals on any attribute that may lead to the perception that another person is different from self". Building on their work and Kassis Henderson's (2005) study on language diversity in international management teams, we define language diversity as variation in the individual board members' mother tongues and the degree of fluency they have in the working language of the board. 
A key question in diversity research has been how differences between group members as an input variable affect group performance as an output variable (van Dijk et al., 2012; van Knippenberg and Schippers, 2007). However, the findings are inconsistent, indicating positive, negative and non-significant performance effects (van Dijk et al., 2012). What becomes clear from these extensive reviews is that the relationship between group diversity, process, and performance is highly complex. Several calls for research have been made to address this issue (Stahl et al., 2010, van Knippenberg and Schippers, 2007; van Dijk et al., 2012). Our study responds to this call by focusing on how language diversity affects decision-making and work processes.

\subsection{Research on language in multinational corporations}

Due to the lack of research on language in corporate boards, we need to turn to the field of international business where the role of language in multinational corporations has been addressed for some time (Marschan et al., 1997). Instead of language diversity per se, international business scholars have explored how the introduction of a common corporate language has been introduced in order to reduce the expected disadvantages of language diversity. More specifically, they have investigated how the adoption of a common corporate language shapes headquarters-subsidiary relationships (Marschan-Piekkari et al., 1999a) and cohesion within the MNC (Barner-Rasmussen and Björkman, 2007). Previous contributions have also addressed the ability of multinational corporations to exercise foreign subsidiary control in environments that are diverse in terms of language (Björkman and Piekkari, 2009; Marschan-Piekkari et al., 1999a), inter-unit knowledge sharing (Mäkelä et al., 2007), individual status loss (Neeley, 2013), language as power in crossborder mergers (Vaara et al., 2005), and language policies and practices (Luo and Shenkar, 2006; Peltokorpi and Vaara, 2012). 
The research outlined above shows that language permeates virtually all of the management processes within the multinational corporation. Yet, language barriers that potentially impede efficient operations of the multinational corporation have been uncovered at organizational levels below the board (e.g., Marschan-Piekkari et al., 1999a, Mäkelä et al., 2007, Neeley, 2013). Top management has been shown to be much more comfortable operating in the common corporate language than have middle management or operative employees (MarschanPiekkari et al., 1999a). Moreover, in international business research, the language-performance link has remained elusive (see, Luo and Shenkar, 2006, for an exception) because past literature has primarily focused on the effect of language on international management processes.

A limited number of studies in international business touch on the role of language in team dynamics. Schweiger et al. (2003) studied nine transnational project teams in multinational corporations such as Sony, Alcatel, Air Liquide and Sonoco Products. These teams, which were nationally and functionally diverse, were involved in knowledge creation that was to be incorporated in products and services. Although the authors were primarily interested in the impact of context on teams, the role of leadership, and how teams function, their findings suggest that "language may be an even bigger potential problem than functional differences and culture per se" (Schweiger et al., 2003, p. 134, italics in the original). Lagerström and Andersson (2003) investigated a team of a Swedish multinational corporation and its information technology unit. They write that the problems associated with the global team members' lack of proficiency in English, the common corporate language in this case, had not been foreseen. Lagerström and Andersson (2003, p. 94) conclude that the "creation and sharing of knowledge within a transnational team rests upon efficient communication and interaction, which is critically enhanced by mingling social interaction with work interaction, which in turn is facilitated by regular meetings and proficiency in a common business language". 
Kassis Henderson's (2005) research on international management teams is a rare example of a study that specifically focuses on language diversity. She studied how language diversity, from a sociolinguistic perspective, operates in everyday interactions of English-speaking teams which were composed of French, German and British managers working in France. Her findings suggest that socialization processes, such as building of trust and relationships among team members, are language dependent. When speaking a foreign language, team members tend to employ their own native language strategies and cultural rules, which create multiple problems. Kassis Henderson argues that in language diverse teams problems are not solved by the simple recourse to English and calls for increased language awareness and sensitivity among both international team leaders and members.

Turning to the field of anthropology, SanAntonio's (1987) ethnography of a US-owned subsidiary in Japan uncovers the consequences of implementing a strict monolingual English-only policy. Despite this corporate-level policy, the subsidiary was still linguistically diverse. Both the Japanese employees and the American expatriates employed the language of the "other" as a tool to adjust their identities. The willingness of the Japanese employees to use English in a range of situations marked their desire for social inclusion and integration into the American corporation. SanAntonio also observes that in meetings where all of the Japanese attending had approximately the same level of fluency in English, language was not an issue. However, when Japanese employees with varying English skills were present at the same meeting with foreigners in attendance, one employee tended to dominate and the meeting was noticeably quieter than those attended by Japanese only. The input from the Japanese was reduced and funnelled through the English proficient Japanese employee. In this way, the English policy circumvented the indigenous Japanese hierarchy and changed the social structure in the subsidiary.

Experimental studies in psychology provide additional insight into the effect of foreign language use on decision-making and judgment, although none of these studies have been 
conducted in multinational corporations. The six experiments conducted by Keysar et al. (2012) strongly demonstrate that individuals' solution to a problem varies according to whether they use their native tongue or a foreign language in making the decision. The authors explain that a foreign language provides the decision-maker with greater cognitive and emotional distance from the task at hand. The decision-maker reacts less emotionally and intuitively in a foreign language and relies more on analytic, deliberate modes of thinking than when using a native tongue. Emotions play an important role in decisions about e.g. investments and risks which are highly relevant for board work. Based on two experiments, Takano and Noda (1993) show that individuals who use a foreign language that they do not master as well as their native tongue experience a temporary decline in concurrent thinking ability. According to Takano and Noda this is because communicating in a foreign language places a heavier linguistic processing load on the individual. The above studies in the field of psychology empirically establish the link between communicating in a foreign language and the individual's cognitive processes, such as decisionmaking.

\subsection{Research on communication and shared language in board processes}

Many of the factors identified above are considered together when examining language diversity in corporate boards with foreign members. Corporate boards in publicly traded firms are relatively large and interdependent decision-making groups, and typically face complex tasks that necessitate interaction among board members. We concur with Smith et al. (1994) who state that for any group to interact effectively its members need to be able to communicate easily. Board work requires a high degree of specialized knowledge and skills, which foreign members can potentially bring to the board (Luo, 2005). However, the mere presence of valuable expertise does not ensure that it will be used by the board (Forbes and Milliken, 1999) - particularly if it resides 
behind the language barrier. Based on a conceptual model of strategic decision-making effectiveness in US-based boards, Forbes and Milliken (1999, p. 499) maintain that because board members meet only periodically, "they are unlikely to have time to fully resolve the attitudinal and linguistic differences that divide them". While they do not elaborate on what they mean by "linguistic differences" in the US context, they argue that boards are particularly vulnerable to "interaction difficulties that prevent groups from achieving their full potential" (Forbes and Milliken, 1999, p. 492).

Extensive communication is not only necessary for integrating individual board members' knowledge and skills in creative and synergistic ways and applying them to the board's tasks, but also necessary for conflict resolution (Stahl et al., 2010). Forbes and Milliken (1999) identify cognitive conflict, i.e. differences in judgment among board members about the task at hand, as a key and beneficial process in board work. They explain that such conflicts are likely to arise as a result of the very nature of board work. In fact, cognitive conflicts contribute to the quality of decision-making in uncertain environments. Multiple viewpoints and alternative solutions are more carefully evaluated and considered when both positive and negative views are exchanged.

To support board work in terms of knowledge exchange and informed decisionmaking, multinational corporations with foreign board members may change their working language to English. Stahl et al. (2010, p. 693), who conducted a meta-analysis of cross-cultural teams, reason that individuals should have "at least a minimum of a shared language around which to align". English as a new working language of the board can be argued to reduce language diversity. However, whether board members actually perceive there to be a shared language that reduces language diversity is not straightforward; a point suggested by Kassis Henderson's (2005) research on international management teams. She argues that when English is used, team members "are under the false impression that they are sharing the same context and the same interpretation; 
that the same words and expressions have the same connotations for speakers of English from, say, the United States, India, France, and Denmark" (2005, p. 75). This is an illusion because team members tend to draw on different interpretive frameworks originating from the language systems of their respective mother tongues (Kassis Henderson, 2005). As is the case with international management teams, not all board members will necessarily consider English as a shared working language, and its use may in fact disguise a high degree of language diversity.

Thus far, we have primarily covered aspects of internal communication within the board. However, the adoption of English as the working language of the board also has implications for communication with the executive management team and for communication with other internal stakeholders. In non-Anglophone firms the executive management team needs to be prepared to receive strategic advice from the board in English. English speaking subsidiary employees may also become more committed and motivated if English is introduced at the apex of the organization (Marschan-Piekkari et al., 1999b). In this regard, a more uniform use of English can be expected to enhance internal communication, thus boosting what Oxelheim et al. (2013) highlight as commercial internationalization of the firm.

In relation to external stakeholders, the adoption of English as the global lingua franca of finance paves the way for reaching out to new groups of investors. Past research highlights that increased compliance with the Anglo-American corporate governance system signals commitment to a harsher corporate governance monitoring regime (Oxelheim and Randøy, 2003). By recruiting foreign board members the firm also sends an important signal that it respects equal career opportunities regardless of the colour of the individual's passport. Hence, external communication in English can be expected to be especially associated with the firm's financial internationalization (Oxelheim et al., 2013). Likewise this applies to the recruitment of female board members whose entry may signal gender equality and the absence of the glass ceiling (see, Terjesen et al., 2009, for a review). 
Based on the broad literature review above, we conclude that the role of language in board processes is yet to be fully understood. We therefore pose the following research question: How does increased language diversity affect decision-making and work processes of the board?

\section{A MULTIPLE CASE STUDY AND ITS RESEARCH CONTEXT}

Our research design is a multiple case study of the corporate boards in nine Nordic multinational corporations, supplemented by a uniquely collected data set drawn from the population of corporate boards among publicly traded firms from the Nordic countries. Using this mixed method approach is in line with the recommendations of Shah and Corley (2006), and allows us to triangulate the case companies with the broader population of corporate boards. We are interested in exploring and explaining (Yin, 2009) how the entry of a foreign board member influences language diversity and affects decision-making and work processes of the board. The research design allows us to set boundaries around the effect of language diversity on board processes and capture the phenomenon in its natural context.

In addition to detailing the rationale for case selection, data collection and analysis, we also account for the research context in our study. Joshi and Roh (2009, p. 622) encourage researchers to undertake a "contextual diagnosis" because diversity in organizations is highly sensitive to context. Therefore, we introduce the reader to the specificities of the corporate governance systems in the Nordic region and in interpreting our findings highlight the role played by the commercial and financial internationalization of the firm. 


\subsection{The Nordic region as a research context}

Since the Nordic region has only about 25 million consumers, it represents a small "domestic" market which incentivizes Nordic firms to internationalize in order to benefit from economies of scale. According to UNCTAD (2012), relative to the size of the economy the Nordic countries headquarter the largest share of multinational corporations in the world. However, there have also been restrictions on the internationalization of ownership and the recruitment of corporate boards. Until the early 1990s Nordic countries were characterized by regulatory barriers that limited officially for accountability reasons - the recruitment of foreign board members. With the implementation of the EES (European Economic Space) tractate in 1994, such restrictions on the recruitment of foreign directors - including various residence requirements - could only be applied to non-Europeans.

The corporate governance systems in the four Nordic countries selected for the present study - Denmark, Finland, Norway, and Sweden ${ }^{1}-$ are rather similar and can be seen as a modified version of the German corporate governance system, with a strong focus on the alignment of interests between managers and industrial corporate owners (Angblad et al., 2001). Firms from these countries were formerly governed by extensive capital controls, particularly prior to the 1990s. Thus, we find it relevant that our case companies are drawn from four transparent and export-oriented economies that, particularly during the last two decades, have opened up to a global capital market and to foreign board membership (Oxelheim et al., 2013). ${ }^{2}$

\footnotetext{
${ }^{1}$ We have left out Iceland due to its small size.

${ }^{2}$ A careful reading of the corporate governance codes in the Nordic countries reveals that none of them addresses directly the issue of language, or international representation. However, it should be noted that the Swedish code indirectly mentions the issue of international board representation by stating that in the recruitment of board members "[t]here should be a balance between [representatives of] Swedish and international capital markets.", http://www.corporategovernanceboard.se/about-the-board/composition
} 
The four Nordic countries included in this study have a number of linguistic ${ }^{3}$, cultural and legal aspects in common. Of the four languages in our study, three - Danish, Norwegian and Swedish - resemble each other. They are Scandinavian languages and belong to family of Germanic idioms. The fourth, Finnish, deviates from the rest and is not readily understood by Danes, Norwegians or Swedes because it belongs to the family of Finno-Ugric languages. The Nordic countries have had a long history of independence (Denmark and Sweden), or have been colonized by one of the other Nordic members (Norway and Finland). This has created an appreciation for self-governance, and the use of national languages. It has also contributed to a corporate environment that can be characterized as a "small world" in that trust, information and reputation of individual board members spread quickly and shape board behaviour (Sinani et al., 2008). The existence of employee representatives on the corporate board (not in Finland, but in most cases in Denmark, Sweden and Norway) is a special regulatory feature that makes the Nordic countries an even more interesting laboratory for a study of language diversity. Put together, this has created barriers to the inclusion of foreign board members and made a transition to English as the working language of the board all the more difficult.

\subsection{Case selection}

In order to identify relevant case companies at the beginning of 2007, we used secondary data to get an overview of all the listed firms in Denmark, Finland, Norway, and Sweden. The data collection covered the period 2001-2007, but due to limited availability of information, collection was restricted to the following variables: directors' first name and surname, birth year, date of first appointment to the board, role on the board (e.g., chairperson, employee representative), gender, and nationality. After several rounds of data collection we settled for a rich but unbalanced panel

\footnotetext{
${ }^{3}$ Although the first official language of Finland is a non-Scandinavian language, the second language is Swedish which is spoken by about $6 \%$ of the population.
} 
consisting of 431 firms in the year 2001, 471 firms in 2002, 493 in 2003, 518 firms in 2004, 537 in 2005, 757 firms in 2006, and 678 in 2007.

Based on the above data, Table I shows the share of foreign board members in publicly traded firms in the Nordic countries. Even though there has been a trend towards more foreign board members in all countries between 2001 and 2007, the overall share of foreign board members is still relatively small (from between $6-11 \%$ in 2001 to between $9-14 \%$ in 2007). The most significant change occurred in Finland, where the share of foreign board members doubled from 6 percent to 12 percent over the period. This increase can partly be explained by the fact that in 1997 the Finnish government set a goal to increase the number of women on boards of stateowned enterprises. Furthermore, in 2004 the Finnish equality programme required that both genders need to be represented by at least 40 percent on boards of state-owned enterprises. This paved the way for a rapid change in both female board membership and indirectly the number of foreign board members, as new female members were more likely to be recruited from abroad (mostly from Sweden). The high increase in foreign board membership in Norway is partly associated with the legislation in 2003 requiring at least 40 percent board representation from each gender. This has been fully implemented since early $2008 .^{4}$

Age diversity of boards is remarkably similar across the four countries and appears to have changed very little over the period. Average board age is 53 years and most board members tend to be 46-60 years old. Younger board members tend to have a higher degree of personal internationalization and better language competence than their older counterparts.

\section{INSERT TABLE I ABOUT HERE}

\footnotetext{
${ }^{4}$ In 2008 non-compliant companies could be dissolved.
} 
From the panel data we selected nine companies for our study. These were (in alphabetical order): Biohit, Danisco, Ericsson, Expert, ISS, Nokia, Novozymes, Outokumpu, and Simrad Optronics. Three of these firms were headquartered in Finland, three in Denmark, one in Sweden, and two in Norway. We selected the case companies based on purposeful sampling (Fletcher and Plakoyiannaki, 2011; Yin, 2009) and applied two main criteria which were central to our study: (1) the firms' degree of internationalization and (2) the number of foreign board members.

Firstly, we separated between commercial internationalization in terms foreign sales and financial internationalization in terms of being listed on foreign exchanges. Whereas the first aspect of internationalization has been addressed by prior studies (Luo, 2005), the second has only recently been included (Oxelheim, et al., 2013). As can be seen from Table II, in 2007 firms with a majority of sales from foreign markets did not "automatically" recruit foreign board members. In a similar way, foreign stock exchange listing did not imply the recruitment of foreign board members.

INSERT TABLE II ABOUT HERE

Secondly, in 2007 all of the nine firms had at least one foreign board member. While six firms had two or more, Biohit, Expert and Simrad Optronics had only one foreign board member (see Table II). This distinction is important because only one "diverse" board member can be seen as a mere "token" member who alone will not be able to influence or change board work. Recently, Torchia et al. (2011) found in their study of female board recruits that there is a minimum threshold in order for female members to have an impact on board processes. This research finding is in line with Kanter's (1977) critical mass theory. 


\subsection{Personal interviews}

As Table III shows, a total of 30 personal interviews were conducted which formed the main source of data in our multiple case study. These interviews were held with chairpersons of the board, current and former board members, and managing directors of the case firms when possible, in order to gain a historical perspective. More specifically, five of 30 interviewees were female, four were conducted with former board members, and 10 with foreign members. We had very good access to these companies and the directors including the chairmen of the two global telecom giants, Ericsson and Nokia, devoted a considerable amount of their time to the interviews.

\section{INSERT TABLE III ABOUT HERE}

Although qualitative process data are particularly suitable for understanding complex temporal dynamics such as board processes, diversity research has been characterized by an "absence of process data" (van Dijk et al., 2012, p. 49). Thus, our personal interviews aimed at capturing the personal experience of board work from board members and CEOs. The retrospective nature of our study allowed us to back trace the change in the board's working language to the early 1990s, when the first foreign members joined the boards of our case companies. We also identified other key internationalization events of the case companies, such as internationalization of sales over time, establishment of foreign subsidiaries, and the possible listing of the firms' stock on foreign exchanges.

We encouraged our interviewees to contrast and compare their board experiences within their respective case company with other boards of which they were or had been members, or were considering board membership. These interview questions generated vivid additional examples from China, Russia, and the United Arab Emirates, as well as from domestic boards 
with no foreign members. The individual experiences extended our data set beyond the boundaries of the case companies. Moreover, one researcher of our team is a member of a board that had recently changed its working language to English. This first-hand personal experience provided us with additional insight.

The majority of the interviews was tape-recorded and transcribed. However, in a few cases the interviewee would not allow us to tape-record the discussion due to the perceived confidentially of board work. The transcripts demonstrate very clearly how some interviewees found language a sensitive issue and were not comfortable being interviewed about it. In contrast, former board members and managing directors tended to speak more openly about distant board experiences. One of them willingly admitted that "people don't want to speak about things that make them look bad. It's much easier to move on by saying that language is not an issue everybody speaks English!" This quotation demonstrates the limits of interviewing as a data collection method about sensitive issues (Macdonald and Hellgren, 2004). It is less likely that a board member would, in an interview situation, admit to having made a wrong decision or a mistake in board work due to language-based misunderstandings. Our access to companies did not allow us to attend board meetings and observe them in real-time.

The issue of language is also a methodological question in qualitative interviewing (Welch and Piekkari, 2006, Xian, 2008). As a Nordic team of researchers we conducted the personal interviews in Danish, Norwegian, Swedish, Finnish, and English, and matched the interviewee's native tongue with that of the researcher. We believe that such a choice of the interview language contributed to the quality of the interview data. On the other hand, the extensive use of Nordic languages in data collection prevented us from 'testing' the interviewee's ability to speak English, which was the dominant working language of the boards we studied. We used English, Swedish and "Scandinavian", a mixture of Scandinavian languages, in our collaborative work and engaged in a considerable amount of translation when collectively 
analysing emerging research findings and writing them up in English, the reporting language. The crossing of language boundaries and processes of translation in data collection and analysis are seldom accounted for in published research (Welch and Piekkari, 2006). Yet, we believe this type of self-reflection enhances the quality of fieldwork and the credibility of the findings.

\subsection{Data analysis}

The original purpose of the case studies was to explore and explain board internationalization in a holistic rather than variable-oriented way (Ragin, 1992). In the course of the study, language developed into an important theme, which we decided to follow and add to our data collection and analysis as the project progressed (Dubois and Gadde, 2002). Since the centrality of the language theme became evident only during fieldwork rather than prior to starting it, we missed the opportunity to further study one Danish company that had recruited two foreign board members but replaced them because of the language barrier. The evolving nature of our study explains why we did not pose the same language-related questions to all our interviewees. In retrospect, we would argue that because of the unprompted nature of the language theme its influence on board processes is particularly expressive and significant.

A case narrative was written based on each company. The cases were analysed chronologically in terms of the timing and motives of board internationalization and its relationship with the commercial and financial internationalization of the firm. This was followed by a thematic analysis of the barriers to board internationalization, the choice of the board's working language and the influence of language on decision-making and work processes of the board. The nine case narratives formed an important step in the analysis as a means to capture "the contexts, content, and process of change" (Pettigrew, 1990, p. 268). A cross-case analysis, which 
is presented here, was undertaken based on the individual case narratives. In order to enhance the transparency of our analysis, case-specific data are provided in the figures and tables. This is in line with the recommendations of case study guidebooks (Yin, 2009) as well as case study practice (Piekkari et al., 2009).

\subsubsection{Processual data analysis}

We incorporated temporality in our research design in various ways. In Blazejewski's (2011) terms, the case time covered the period from 1897-2009 and the research time during which the interviews took place was 2007-2009. We collected additional secondary data from company annual reports in 2013. We undertook a systematic processual data analysis of two interrelated themes, namely (1) the development of board internationalization over time and (2) the speed and nature of changing the board working language from Nordic national languages to English.

\section{INSERT FIGURE 1 ABOUT HERE}

As Figure 1 shows, our analysis reveals, firstly, that the companies which had internationalized their operations starting from the end of the $19^{\text {th }}$ century (Nokia, Ericsson) and the early $20^{\text {th }}$ century (Danisco, ISS, Outokumpu) brought in the first foreign board member between 1992 and 1998. For example, Ericsson, which established its first foreign subsidiary in 1903 in China after having been present there since the early 1890s, recruited its first foreign board member as late as in 1996. For the companies that had established the first foreign subsidiary later - during the period 2000 to 2007 (Expert, Novozymes, and Simrad Optronics) the timing of internationalizing the board and the establishment of the foreign subsidiary more or less coincided (see Figure 1). If the first foreign board member was not a female (only in the case 
of Novozymes was the first foreign member a female), the first woman on the board was often elected subsequent to the first foreigner board member (see, Table IV for an overview). This was the situation in Danisco, Ericsson, ISS, and Novozymes. In all nine case companies the internationalization of the board followed an extensive process of the firms' commercial internationalization of sales and the establishment of foreign subsidiaries. The two telecom companies, Ericsson and Nokia, were the only case companies that were officially listed on the U.S. capital market during the time of the study. Ericsson listed its shares on the exchanges in London and Paris in 1960 as an important first step in its financial internationalization. Nokia listed its shares in Stockholm in 1983. Both companies recruited the first foreign board member decades later. Thus, this can be seen as a reactive rather than proactive move in the overall internationalization of the firm.

\section{INSERT TABLE IV ABOUT HERE}

Secondly, our processual analysis reveals that the case companies responded to the increasing level of language diversity in their boards very differently. The range of responses led us to categorize the case companies into three groups (see Table II): (1) the well-prepared group, Danisco, Ericsson, ISS, Nokia, Novozymes, which adopted English as the new working language of the board after a long period of "Englishnization" (Neeley, 2012) at the executive management level; (2) the unprepared, Biohit and Outokumpu, which implemented the language change "overnight" in a fairly abrupt and sudden manner; and finally, (3) the outliers - Expert and Simrad Optronics which deviate from the above two groups. We will next turn to our findings. 


\section{FINDINGS}

In this section, we first provide an overview of the increased language diversity in the case companies after the entry of the first foreign board member. We proceed by contrasting and comparing the effects of language diversity on board processes between the well-prepared and the unprepared case companies, and finally discuss the two outliers.

\subsection{Increase in language diversity across the nine case companies}

Our findings reveal that boards had to consider changing the current working language; i.e., switch to English, in order to accommodate the foreign board member. Table $\mathrm{V}$ provides an overview of language diversity in the boards and the executive management teams across the case companies. As can be seen from Table V, we identified three different solutions among the case companies to the increase in language diversity following the recruitment of a foreign board member: 1) a full switch to English as the new working language; 2) no switch (i.e., to continue using a Nordic language in board work); and 3) a hybrid solution. The recruitment of a foreign non-Nordic board member implied a switch to English as the working language of the board, with two exceptions, Expert and Simrad Optronics, which will be discussed separately as outliers.

INSERT TABLE V ABOUT HERE

All the case companies with a high level of foreign ownership (more than 50\%) eventually switched to English as their board language - Ericsson, ISS, Nokia. Of these companies Ericsson and Nokia were officially listed and had a strong need to communicate with external stakeholders. ISS had recently delisted. In contrast, among the case companies with less 
than 50\% ownership, the pattern of adopting English as the working language of the board was not uniform: while some replaced a Nordic language with English (Biohit, Danisco, Outokumpu) others did not (Expert, Novozymes, Simrad Optronics).

In addition to the working language of the board, Table $\mathrm{V}$ also reports the range of mother tongues present among board members. This is in line with Kassis Henderson's (2005) argument that members of language diverse teams revert to their native interpretive systems. We apply Chiswick's and Miller's (2005) measure of language distance between English and the myriad of mother tongues. Chiswick and Miller argue that the greater the language distance, the poorer the individual's proficiency in English is likely to be. As Table V shows, language distance varied from short to medium.

We also paid attention to the working language of the executive management team to deepen our understanding of language diversity in internal communication (see Table V). A shared working language between the executive management team and the board obviously facilitates interaction and collaboration between the two which was the case in all the wellprepared companies.

\subsection{The well-prepared case companies and the carefully managed board processes}

The group of the well-prepared case companies consisted of five firms: Nokia, Nowozymes, Danisco, Ericsson, and ISS. Let us start with Nokia. Nokia switched the language of board meetings from Finnish to English when the first foreign board member joined the board in 1992. Most of the written material for board meetings had already been prepared in English before 1992. In this regard, language change crept in through the back door and "the board was the last place in the corporation where the shift to English had been made for good", as one of our interviewees said. 
A major reason for this easy transition was the presence of foreign executives on Nokia's executive management team. The smooth change in board language was explained by the extensive use of English language in Nokia's daily activities. The firm was radically transformed in the early late 1980s and 1990s when it divested non-core businesses and focused on telecommunications. As the Nokia chairman clarified, the company was renewed and rejuvenated with the departure of the old management. For the younger generation of managers, engaging in international business and speaking English was self-evident and very natural. As a foreign member of the executive committee put it:

Nokia is very strict with the use of English. Our meetings are in English, we write in English, and people are very... very much attuned to [English], [they] don't fall back into Finnish... and don't make it awkward for people that don't speak Finnish, whether they're Chinese or they're American or they're from Brazil, you know.

Compared to our interviews in other Nordic companies, the Nokia representatives appeared exceptionally comfortable in using English as their working language. Nokia has a written language policy specifying the choice of language and its use, even down to the level of the appropriate tone of voice (Kangasharju et al., 2010). Some of our interviewees at Nokia were almost taken aback by our questions concerning the effect of English on board dynamics. Even in Nokia units in Finland, Finnish colleagues would frequently send each other e-mails in English in case the message would be forwarded to a non-Finnish-speaking colleague. As a Finnish board member explained: 
Language is not an issue. It cannot be. And if it was an issue for someone, it becomes the personal problem of the individual in question. It is then for this person to look for other employment opportunities. It [speaking English] is so self-evident here.

The Nokia case is an example of a proactive, highly global company that started to use English at the board level long before the first foreign board member was recruited, albeit not yet as the official language of board meetings. Because of its early financial internationalization Nokia was faced with a need to communicate with investors, regulators and other stakeholders worldwide. Although the Nokia board had completely switched to using English, board minutes were still written in Finnish whenever the board made decisions that Finnish authorities needed to be informed about (e.g. the appointment of a new CEO needs to submitted to the business registrar) or alternatively an official translation of the board minutes into Finnish was provided ${ }^{5}$. The Nokia experience is very similar to the Swedish case Ericsson, which also started to use English long before the first foreign board member was recruited. This suggests that during the time of our study (2007-2009), the legal framework had given way to the language switch.

In the Danish firm Novozymes, three of the seven shareholder-elected board members were foreign in 2007; one from Norway and two from Sweden. The composition of the board had remained the same since the establishment of the firm in 2000 . The board meetings were held in Danish due to the preference of the employee representatives. The CEO noted that a potential switch from Danish to English could be interpreted as an attempt to exclude employee representatives from discussions in board meetings. In early 2008, however, Novozymes started to prepare the documents for the board meetings in English and the employee representatives were entitled to translation services upon request. The CEO was of the opinion that Novozymes would

\footnotetext{
${ }^{5}$ Likewise, in Norway the official annual report, which has to be written in Norwegian, is issued and signed by the board. However, the board may also approve the English translation.
} 
benefit from a truly international board with no employee representatives on the board. ${ }^{6}$ The shareholder-elected board members did not find English problematic but we did not have the opportunity to interview the employee representatives themselves. While Novozymes kept the language of board meetings intact, the entry of foreign board members gradually changed the language of the written materials prepared for board meetings from Danish to English. It also triggered the provision of translation services for the employee representatives.

In another Danish case company, Danisco, the first foreign member from Sweden joined the board in 1993 and left in 2005. In 1999 two Finns joined the board as a result of an acquisition. Thus, Danisco's board was strongly Nordic. Yet, these members were believed to be internationally oriented and to have a broad range of managerial experience. Danisco had had negative experiences of a foreign board member who was recruited outside the Nordic region due to this individual's failure to actively participate in and contribute to board meetings because of insufficient fluency in English. The person was therefore ultimately replaced.

A further examination of the Danish cases (Danisco, ISS, and Novozymes) shows that they had the highest share of employee board representatives among the Nordic firms. The Swedish firm Ericsson provides supporting evidence: two shareholder elected board members mentioned independently that operating in English was a challenge particularly for some employee representatives. Hence, the co-determination acts introduced in the Scandinavian countries in the late 1970 s and early 1980 s carry a cost in relation to board internationalization (Oxelheim and Randøy, 2003), delaying the change in the board's working language. We maintain that the challenges associated with language switch were also experienced in well-prepared companies. Taken together, however, these companies were highly aware of language issues and had dealt with them in a gradual and diligent manner.

\footnotetext{
${ }^{6}$ As long as the company is incorporated in Denmark and of a size that Novozymes exceeds, employee representation on the board is required by Danish law.
} 


\subsection{The unprepared case companies and the silencing effect on board processes}

The group of unprepared case companies consisted of two Finnish firms, Outokumpu and Biohit. As Table $\mathrm{V}$ shows, the board members were separated by a medium language distance and the native Finnish members were not able to actively participate in board meetings which were conducted in a foreign tongue, English. This had negative effects on board processes: board members interacted significantly less with each other and the board meetings themselves were shorter than before the introduction of English. These findings are in sharp contrast with the group representing the well-prepared case companies.

In the Finnish firm Outokumpu, in which the state retained a 31percent ownership in 2007, the change in working language was a total one-off change rather than an incremental process. The first foreign board member was elected in 2003 as a consequence of a cross-border acquisition. In line with the spirit of regulatory barriers existing prior to EU membership the state of Finland was initially opposed to foreign board membership, but the Outokumpu chairman of the board at that time was a key driver in internationalizing the board. However, neither the chairman nor any of the board members were fully prepared for the change in working language. As the first foreign board member of Outokumpu recalled:

...they decided [that] rather than having an interpreter we would do it [have the board meetings] in English. Not all members at that time spoke English well. In fact two of them were very poor English speakers. 
For this reason, the Outokumpu chairman stressed his responsibility in ensuring that board members be equipped with sufficient language competence.

You have to make sure that all board members have equal communication skills and capabilities in the language that is being used. And at that time [of the language switch] the situation was a bit different.

One of the former board members at Outokumpu recalled how she used to take English language classes in order to improve her ability to express herself during board meetings. Overall, neither individual board members nor the rest of the Outokumpu organization were prepared for the significant English proficiency requirements at the time of the language change. The recruitment of the foreign members to Outokumpu's board was partly motivated by the demand to recruit more women to boards of state-owned enterprises - not by the demands of the executive management team, whose members were all Finnish at the time, nor by the demands outside foreign owners.

Another Finnish case company, Biohit, experienced a major turnaround in terms of the working language of the board. Initially, when the first and only foreigner from the UK joined the board for two years in 2006, English was introduced as the new working language. This shift was experienced as challenging: all the board material was translated from Finnish to English and the board members, including the chairman, had to learn the key vocabulary in English. Perhaps not surprisingly, when the non-native member left the board in 2008 the language reverted back to Finnish. The departure of the foreign board member was explained by poor transportation connections between his home town outside London and Finland, and by the high relative costs of having a foreign board member for this medium-sized company. During the personal interview, 
Biohit's chairman sceptically uttered, "the boardroom is the last to internationalize, if it globalizes at all!"

\subsubsection{Failure to contribute to board work}

In Outokumpu, the work in the boardroom became strained and difficult after the change of working language from Finnish to English. One board member reflected upon the language change, which took place in 2000 :

It is self-evident that when you are expected to express yourself in English, language becomes a crucial issue. Let's put it this way, when the working language shifted to English, the discussion was limited...

The Outokumpu chairman commented that the introduction of English rendered the quiet board members even quieter. One of them, who had left the Outokumpu board at the time of our study, highlighted:

I do think the shift in language affected my own behaviour in that I was even less eager to speak... I was not the most talkative board member anyway. I lacked the specialized vocabulary and I could not use everyday English to express the issues that I had in mind during the board meetings. 
Overall, this former board member was very critical of the fact that no one on the Outokumpu board spoke his or her mother tongue. She pointed out that in Finnish-speaking boards, of which she was also a member, the communication and actual board work tended to be more effective because the discussion was carried out in the board members' shared mother tongue:

It is clear that certain nuances can only be expressed effectively in your mother tongue... When you use a foreign language, it becomes more technical.

\subsubsection{Failure to disagree and debate}

In the second unprepared company, the Finnish Biohit, the chairman of the board explained how the quality of the discussions at board meetings had suffered. He found it particularly difficult to argue and disagree in English as a non-native speaker. "The board meetings of Biohit have become very polite as the discussions have been toned down", he explained. As mentioned previously, once the sole foreign board member departed, Finnish was quickly reintroduced as the working language. The unpreparedness for the language switch can be interpreted in the light of the working language of Biohit's executive management team which was Finnish as well as the degree of its commercial and financial internationalization. Although Biohit was highly commercially internationalized at the start of the research period and had established subsidiaries

in France (1991), the UK (1992), Italy (1992), Germany (1995), the US (2000), Russia (2000), and China (2003) for example, its financial internationalization was very modest. Biohit went public in 1999, but the foreign ownership was insignificant.

Turning back to Outokumpu, the former CEO shared this view about the challenges associated with not being able to communicate in a nuanced way: 
You may speak fluent English but the kind of English that is required here is different.

Even people with a lifetime of international experience can be impeded by the use of a non-native language. In 2010, Carl-Henric Svanberg, the Swedish-born chairman of the oil giant BP, made an effort to communicate compassion to the victims of the oil spill disaster in the Mexican Gulf. However, a linguistic blunder made the difficult situation even worse. Rather than showing concern for ordinary people, the chairman managed to upset the reporters by speaking about the victims as "small people" - a term that native English speakers interpreted as derogatory language. The blunder spread like wildfire and was soon in the international headlines, causing substantial "badwill" for BP in its external communications. ${ }^{7}$ The chairman of BP was also one of our interviewees, albeit at the time of data collection he was a member of the board of Ericsson and its CEO.

\subsubsection{Social exclusion}

A foreign board member from Outokumpu referred to the occasional use of the domestic language, Finnish, at board meetings. She pointed out that "when they start speaking Finnish during the breaks I do not understand what they say" which caused social exclusion. Moreover, the annual general assembly of shareholders is held in Finnish with all the supporting material prepared in Finnish since many of the owners are Finnish.

\footnotetext{
${ }^{7}$ See: Washington Post, 2010-06-17, “BP chairman talks about the 'small people' further angering gulf” or: http://www.washingtonpost.com/wp-dyn/content/article/2010/06/16/AR2010061605528.html
} 
The Outokumpu chairman said that successful implementation of a new working language of the board requires a certain critical mass of foreign members in order to avoid social exclusion. He expressed this with humour:

One ape is not enough; you need two apes [i.e. foreigners]! One foreigner on the board is too lonely and the others tend to revert to their own mother tongue. In order to alter the prevailing way of doing things you need two [foreigners] at once.

On the other hand, English as a working language was also regarded as an equalising factor. For example, since nobody on the Outokumpu board had English as his or her mother tongue it created a mutual challenge for board members. One foreign board member put it this way:

Everyone speaks English really all through. So that's really very good...sometimes it's difficult not to speak your own mother tongue but on the other hand it's an equal situation for all of us.

For the board members in the well-prepared and unprepared case companies the introduction of English as the board language meant that nobody was permitted to use his or her mother tongue in meetings that were commonly held at the premises of corporate headquarters. It was the combination of not being able to use the language of the parent company in the home country of the firm that caused behavioural and emotional reactions among our interviewees. Thus, our findings demonstrate that the question of language switch was not a mere technical issue. 


\subsection{The outliers: Two hybrid solutions}

We identified two outliers among our case companies that could not be categorized as either wellprepared or unprepared. In response to the increase in language diversity among board members, these firms opted for a hybrid solution. They were both from Norway; Expert and Simrad Optronics. Expert did not change the working language of the board. Rather, the board used "Scandinavian" in all its meetings allowing each member to converse in his or her own mother tongue. Expert's board included one foreign board member from Sweden who was recruited in 2007. Another member, a Norwegian national, lived in the Baltic States, bringing in additional international expertise. The chairman felt a more pressing need to internationalize the executive management team rather than the board. Expert's deliberate strategy was founded on the benefits of a more international board while maintaining the costs at a reasonable level by recruiting internationally minded, multilingual board members from Scandinavia.

The second outlier was Simrad Optronics, which kept the working language of the board intact, but allowed some use of English. This hybrid solution was driven by the recruitment of an American woman who joined the board in 2005. She had lived in Norway for over a decade and was able to participate in the board meetings in Norwegian. The fact that she was American was considered an advantage in order to "sell" stock to foreign investors. During her tenure foreign ownership increased from virtually nil in 2005 to 13 percent by the end of 2007 . Given the firm's need for a more internationally experienced board, particularly because they operated in a high-tech defence manufacturing sector, the company decided to establish an advisory board of foreign experts. This solution provided access to outside expertise as well legitimacy in relation to foreign military customers while avoiding the legal and management obligations associated with regular board membership. It also allowed the board to continue using mostly Norwegian in its meetings. Simrad Optronics is a relatively small company and could not afford high levels of 
remuneration to foreign board members in relation to the perceived risks and responsibilities of being a corporate board member.

\section{DISCUSSION}

We argue that this study changes the way board internationalization should be understood. In relation to existing research, our study goes beyond observing various dimensions of diversity per se and explains how the entry of the foreign board member and the subsequent language switch affect the way the board functions. Our findings suggest that a change in the working language of the board may even silence the board. The two unprepared case companies, which introduced the language switch in a sudden, almost abrupt manner, experienced a silencing effect in their board meetings. In these companies the introduction of English caused less "productive" disagreements and resulted in weaker debates in board meetings. Among our case companies we noted that some board members were "forced" outside their comfort zone and were thus not able to fully contribute to board discussions. This affected negatively their access to information, reduced their interaction with other board members and potentially lowered the quality of decision-making. We also found examples of social exclusion when board members felt they were marginalized and not able to participate in discussions due to the language barrier.

We noted that the two unprepared companies were not as commercially and financially internationalized as the well-prepared companies where English was often first adopted as a medium of communication in the executive management team. These firms were highly aware of language issues: they made translation services available to employee representatives and started to train them in the use of English by preparing the documents for board meetings in English. In the well-prepared case companies the effect of language diversity on board processes was carefully managed as they undertook the language switch in a step-wise, gradual manner. 
Overall, our findings emphasize the importance of diligently managing the change associated with the board language and the entry of the first foreign member.

Figure 2 provides an answer to the question of why we identified the particular language effects we did in the case companies. It visually presents the underlying mechanisms that connect board (de-)internationalization, language diversity, and the effects on board decisionmaking and work processes with each other. Our contextual explanation builds on the firms' degree of internationalization, both commercial and financial, as well as its level of preparedness to undertake a language switch. Figure 2 shows that changing the working language of the board goes far beyond being a simple technical matter. The shift away from using the domestic language to English at the corporate level is likely to affect the entire firm.

INSERT FIGURE 2 ABOUT HERE

Support for our novel finding of the silent board can be found in previous research, albeit conducted below the board level. Lauring and Tange (2010) identified a similar reduction in the overall level of communication in their study of English as a common corporate language in 14 international companies based in Denmark. Research on cross-cultural teams also provides supporting evidence of the silencing effect. Schweiger et al. (2003, p.134) refer to one of their interviewees, a team leader, who confessed that several team members "just could not find the words to express themselves" although English was the official language of the corporation. Consequently, the team could not draw on the full depth of these members' capabilities. While these contributions to international business research have uncovered the effect of language diversity on international management processes, our findings point to the linkage between language and performance (see Luo and Shenkar, 2006, for a conceptual discussion). Since we 
focus on the corporate board - a strategic decision-making body in the MNC - language diversity may have serious consequences for both board and firm performance in the unprepared case companies.

Our empirical evidence suggests that the implications of language diversity for board processes need to be understood in tandem with the motives of a company's internationalization strategy, specifically in relation to commercial and financial internationalization of the firm's activities. In fact, one of our case companies, Biohit, chose to de-internationalize the board and revert back to using the national language, Finnish, in board meetings when the one and only nonFinnish speaking foreign member left the board. We would argue that Biohit's low degree of financial internationalization and the limited need to communicate with international investors and regulators explains this. The upper part of Figure 2 illustrates the interconnectedness between board (de-)internationalization, the motives behind it and the board's working language.

Our findings confirm the results by Oxelheim et al. (2013) that board internationalization is one of the last steps in the internationalization process of the multinational corporation. Even though Nordic companies are among the most internationally oriented firms in the world in terms of foreign sales, employment and ownership (UNCTAC, 2012), the level of foreign board membership is relatively low. Nokia and Ericsson, two of our case companies, recruited their first foreign board members as late as in the early and mid-1990s respectively. This study extends prior research by introducing a language-centred explanation to a surprisingly slow internationalization process of corporate boards. As Figure 2 shows, the presence of employee representatives on the boards further slows down board internationalization because these members often lack the required English proficiency in the common working language of the board. 
Our study also contributes to diversity research by exploring the distinct effect of language diversity on decision-making and work processes in boards. The international angle to diversity research has primarily covered culture rather than language as a dimension of diversity (see, Stahl et al., 2010, for a review). By disassociating language from culture we show that some of the challenges that board members experience when interacting with each other stem from an increase in language diversity. English as the "common" working language may not be as unproblematic as often assumed, because board members still revert to their mother tongues when interpreting board interaction. Similar to research on management teams in general (Kassis Henderson, 2005), language diversity shapes and steers decision-making and work processes of the board.

\section{CONCLUSION AND MANAGERIAL IMPLICATIONS}

Previous research shows that firm internationalization may lead to better financial performance at the firm level and create wealth at the country level (Dunning and Lundan, 2008). In order to reap these benefits, firms may internationalize their corporate boards (Oxelheim et al., 2013). We respond to the call for more research on corporate governance in multinational corporations (Delios, 2011) and board behaviour (e.g., Ees et al., 2009; Forbes and Milliken, 1999) by focusing on decision-making and work processes within boards. Our particular take on this topic is language diversity and its effect on board decision-making and behaviour.

In this study we investigate companies that were well-prepared and unprepared for the internationalization of their boards, and the subsequent change of the board's working language. The study shows that in the unprepared case companies the language switch shortened board meetings and reduced open, constructive disagreements within the board. Furthermore, the board members and top executives interviewed were of the opinion that the language switch 
ultimately hampered decision-making and negatively affected communications. In the wellprepared case companies the situation was the opposite: they benefited from the language switch as it enhanced further internationalization, both commercially and financially.

Our results provide support to the recent findings of Oxelheim et al (2013). They argue that companies motivated by financial internationalization typically recruit foreign board members, particularly Anglo-American, who are expected to create greater confidence among international investors. In two of our case companies, Nokia and Ericsson, board internationalization was particularly motivated by financial reasons, although these motives were also present in five other case companies. Oxelheim et al. contend that companies which can benefit commercially from greater board internationalization are more inclined to hire national board members with international experience. One possible explanation is that commercial internationalization such as foreign market entry is complex enough as it stands. The entry of a foreign board member and the subsequent language switch would render the task even more demanding. The de-internationalization of the Biohit board can be seen as an example of where the costs stemming from board internationalization exceeded the total benefits. In such situations, national board members with international experience may provide a good substitute for the recruitment of foreign board members.

This study is not without limitations. Our data were primarily collected through personal interviews rather than observational data of board meetings. The full effect of language diversity is probably more extensive than indicated by our present findings, at least immediately after the language switch, because of the implicit limitations associated with interviewing as a data collection technique (Macdonald and Hellgren, 2004). The case companies we studied were all headquartered in the Nordic region which represents a linguistically rather homogeneous region with a high degree of English proficiency. We would therefore argue that if switching the board's 
language has a significant effect on the way the board functions in Nordic firms, one would expect the situation to be considerably more challenging elsewhere.

This study offers implications for management. From our case companies, we have learned that the board will experience great difficulties in decision-making and work processes if the board members are not on an equal playing field in terms of fluency in the working language. On the other hand, we observe that there appears to be synergy between the use of the same language in board meetings, in documentation for these meetings, and in communication with the executive management team. It seems that such a consistent use of one language would support transparency and good corporate governance practices. However, stakeholders such as employee representatives, who are required to be included on the board in some countries, may vocally resist the change in the working language of the board. We suggest that the use of translation services in board meetings is rarely an ideal solution in order to close the linguistic gap(s) within the board.

We see a need for further research particularly in three areas: (1) How can the language switch be better understood as a process, from the initial decision to seek a foreign board member, to the impact on work practices in the internationalized board? (2) How does a language switch change major stakeholders' perception of the firm, such as domestic versus international employees, domestic versus international shareholders? (3) How does the language switch impact the role of the home country of the multinational corporation? Is a language switch just the first step on a long journey to leave the home country where the headquarters of the multinational corporation resides? ${ }^{8}$

Reaping the benefits of board internationalization is, in our opinion, the particular management responsibility of the chairperson. Even though English is generally well understood in the Nordic countries, chairpersons should be aware of possible social exclusion due to the

\footnotetext{
${ }^{8}$ There is evidence of such behavior among large Nordic firms such as Astra from Sweden and Nycomed from Norway.
} 
language barrier. A sole diverse board member, whether a foreigner or a woman, is likely to feel isolated and handicapped to the extent they could not make a difference. Nomination committees should also be alerted to the high level of foreign language proficiency needed for effective board work. Owners should be equally aware that 'opening up' the board to foreign members may not only change the working language of the board, but also potentially make the company more open to outsiders, including new investors. This may motivate even more firms to seek highly competent, English-speaking board members and strengthen the trend of board internationalization in the future.

\section{REFERENCES}

Angblad, J., Berglöf, E., Högfelt, P. and Svancar, H. (2001). 'Ownership and control in Sweden: strong owners, weak minorities and social control'. In Barca, F. and Becht, M. (Eds), The Control of Corporate Europe. Oxford: Oxford University Press, 228-58.

Barner-Rasmussen W. and Björkman I. (2007). 'Language fluency, socialization and inter-unit relationships in Chinese and Finnish subsidiaries'. Management and Organization Review, 3, $105-28$.

Barnevik, P. (2011). Jag vill förändra världen (I Want to Change the World). Stockholm: Bonnier.

Björkman, A. and Piekkari, R. (2009). 'Language and foreign subsidiary control: an empirical test. Journal of International Management, 15, 105-17.

Blazejewski, S. (2011). 'When truth is the daughter of time: longitudinal case studies in international business research'. In Piekkari, R. and Welch, C. (Eds), Rethinking the Case 
Study in International Business and Management Research. Cheltenham: Edward Elgar, 251-76.

Bonini, S., Alkan, A. and Salvi, A. (2012). 'The effects of venture capitalists on the governance of firms'. Corporate Governance: An International Review, 20, 21-45.

Chiswick, B. R. and Miller, P. W. (2005). 'Linguistic distance: a quantitative measure of the distance between English and other languages'. Journal of Multilingual and Multicultural Development, 26, 1-11.

Daily, C. M., Dalton, D. R. and Rajagopalan, N. (2003). 'Governance through ownership: centuries of practice, decades of research'. Academy of Management Journal, 46, 151-59.

Delios, A. (2011). 'Governance: the next frontier for research on multinational firms'. Journal of Management Studies, 48, 456-59.

Denis, K. and McConnell, J. (2003). 'International corporate governance'. Journal of Financial and Quantitative Analysis, 38, 1-36.

Dubois, A. and Gadde, L.-E. (2002). 'Systematic combining: an abductive approach to case research'. Journal of Business Research, 55, 553-60.

Dunning, J. H. and Lundan, S. M. (2008). Multinational Enterprises and the Global Economy, 2nd edition. Cheltenham: Edward Elgar.

Ees, H., Gabrielsson, J. and Huse, M. (2009). 'Toward a behavioral theory of boards and corporate governance'. Corporate Governance: An International Review. 17, 307-19.

Fama, E. and Jensen, M. (1983). 'Separation of ownership and control'. Journal of Law and Economics, 26, 301-25. 
Filatotchev, I., Toms, S. and Wright, M. (2006). 'The firm's strategic dynamics and corporate governance life-cycle'. International Journal of Managerial Finance, 2, 256-79.

Filatotchev, I. and Wright, M. (2011). 'Agency perspectives on corporate governance of multinational enterprises'. Journal of Management Studies, 48, 471-86.

Fletcher, M. and Plakoyiannaki, E. (2011). 'Case selection in international business: key issues and common misconceptions'. In Piekkari, R. and Welch, C. (Eds), Rethinking the Case Study in International Business and Management Research. Cheltenham: Edward Elgar, 217-26.

Forbes, D. P. and Milliken, F. J. (1999). 'Cognition and corporate governance: understanding boards of directors as strategic decision-making groups'. Academy of Management Review, 24, 489-505.

Joshi, A. and Roh, H. (2009). 'The role of context in work team diversity research: a meta-analytic review'. Academy of Management Journal, 52, 599-627.

Kangasharju, H., Piekkari, R. and Säntti, R. (2010). The language policy in international firms: where is it hiding? 26th EGOS (European Group for Organizational Studies) Colloquium, New University of Lisbon, Lisbon.

Kanter, R. M. (1977). Men and Women of the Corporation. New York: Basic Books.

Kassis Henderson J. (2005). 'Language diversity in international management teams'. International Studies of Management and Organization, 35, 43-54.

Keysar, B., Hayakawa, S. L. and An, S. G. (2012). 'The foreign-language effect: thinking in a foreign tongue reduces decision biases'. Psychological Science, 23, 661-68. 
Lagerström, K. and Andersson, M. (2003). 'Creating and sharing knowledge within a transnational team: the development of a global business system'. Journal of World Business, 38, 84-95.

La Porta, R., de Silanes, F. L. and Shleifer, A. (1999). 'Corporate ownership around the world'. Journal of Finance, 54, 471-517.

Lauring, J. and Tange, H. (2010). 'International language management: contained or dilute communication'. European Journal of International Management, 4, 317-32.

Luo, Y. (2005). 'How does globalization affect corporate governance and accountability? A perspective from MNEs'. Journal of International Management, 11, 19-41.

Luo, Y. and Shenkar, O. (2006). 'The multinational corporation as a multilingual community: language and organization in a global context'. Journal of International Business Studies, 37, 321-39.

Macdonald, S. and Hellgren, B. (2004). 'The interview in international business research: problems we would rather not talk about'. In Piekkari, R. and Welch, C. (Eds), Handbook of Qualitative Research Methods for International Business. Cheltenham: Edward Elgar, 26481.

Marschan, R., Welch, D. and Welch, L. (1997). 'Language: the forgotten factor in multinational management'. European Management Journal, 15, 591-98.

Marschan-Piekkari, R., Welch, D. and Welch, L. (1999a). 'In the shadow: the impact of language on structure, power and communication in the multinational firm'. International Business Review, 8, 421-40. 
Marschan-Piekkari, R., Welch, D. and Welch, L. (1999b). 'Adopting a common corporate language: IHRM implications'. International Journal of Human Resource Management, 10, 377-90.

Masulis, R. W., Wang, C. and Xie, F. (2012). 'Globalizing the boardroom - the effects of foreign directors on corporate governance and firm performance'. Journal of Accounting and Economics, 53, 527-54.

Miller, T. and Triana, M. C. (2009). 'Demographic diversity in the boardroom: mediators of the board-diversity-firm performance relationship'. Journal of Management Studies, 46, 755-86.

Mäkelä, K., Kalla, H. and Piekkari, R. (2007). 'Interpersonal similarity as a driver for knowledge sharing within multinational corporations'. International Business Review, 16, 1-22.

Neeley, T. (2012) 'Global business speaks English’, Harvard Business Review, 90, 116-24.

Neeley, T. B. (2013) 'Language matters: status loss \& achieved status distinctions in global organizations'. Organization Science, 24, 476-97.

Nielsen, S. and Huse, M. (2010). 'The contribution of women on boards of directors: going beyond the surface'. Corporate Governance: An International Review, 18, 136-48.

Oxelheim, L. and Randøy, T. (2003). 'The impact of foreign board membership on firm value'. Journal of Banking and Finance, 27, 2369-92.

Oxelheim, L. and Randøy, T. (forthcoming). 'Globalization of monitoring practices: the case of American influences on the dismissal risk of European CEOs'. Journal of Economics and Business, Special Issue on International Corporate Governance. DOI: 10.1016/j.jeconbus.2013.02.002. 
Oxelheim, L., Gregorič, A., Randøy, T. and Thomsen, S. (2013). 'On the internationalization of corporate boards: the case of Nordic firms'. Journal of International Business Studies, 44, 173-94

Peltokorpi, V. and Vaara, E. (2012). 'Language policies and practices in wholly-owned foreign subsidiaries: a recontextualization perspective'. Journal of International Business Studies, 43, 808-33.

Pettigrew, A. M. (1990). 'Longitudinal field research on change: theory and practice'. Organization Science, 1, 267-92.

Pettigrew, A. M. (1992). 'On studying managerial elites'. Strategic Management Journal, 13, $163-82$.

Piekkari, R., Welch, C. and Paavilainen, E. (2009). 'The case study as disciplinary convention: evidence from international business journal'. Organizational Research Methods, 12, 56789.

Ragin, C. C. (1992). “'Casing” and the process of social inquiry'. In Ragin, C. C. and Becker, H. S. (Eds), What Is a Case? Exploring the Foundations of Social Inquiry. Cambridge, NY: Cambridge University Press, 217-26.

Roth, K. and Kostova, T. (2003). 'The use of the multinational corporation as a research context'. Journal of Management, 29, 883-902.

SanAntonio, P. M. (1987). 'Social mobility and language use in an American company in Japan'. Journal of Language and Social Psychology, 6, 191-200. 
Sanders, G. and Carpenter, M. A. (1998). 'Internationalization and firm governance: the roles of CEO compensation, top team composition, and board structure'. Academy of Management Journal, 41, 158-78.

Schweiger, D. M., Atamer, T. and Calori, R. (2003). 'Transnational project teams and networks: making the multinational organization more effective'. Journal of World Business, 38, 12740.

Shah, S.K, and Corley, K.G. (2006). 'Building better theory by bridging the quantitive and qualitative divide'. Journal of Management Studies, 43, 1821-35.

Sinani, E., Stafsudd, A., Thomsen, S., Edling, C. and Randøy, T. (2008). 'Corporate governance in Scandinavia: comparing networks and formal institutions'. European Management Review, 5, 27-40.

Smith, K. G, Smith, K. A., Olian, J. D., Sims, H. P. Jr., O’Bannon, D. P. and Scully, J. A. (1994). 'Top management team demography and process: the role of social integration and communication'. Administrative Science Quarterly, 39, 412-38.

Stahl, G. K., Maznevski, M. L., Voigt, A. and Jonsen, K. (2010). 'Unraveling the effects of cultural diversity in teams: a meta-analysis of research on multicultural work groups'. Journal of International Business Studies, 41, 690-709.

Takano, Y. and Noda, A. (1993). 'A temporary decline of thinking ability during foreign language processing'. Journal of Cross-Cultural Psychology, 24, 445-62.

Terjesen, S., Sealy, R. and Singh, V. (2009). 'Women directors on corporate boards: a review and research agenda'. Corporate Governance: An International Review, 17, 320-37. 
Torchia, M., Calabro, A. and Huse, M. (2011). 'Women directors on corporate boards: from tokenism to critical mass'. Journal of Business Ethics, 102, 299-317.

\section{UNCTAD (2012). World Investment Report. Geneva: UNCTAD}

Vaara, E., Tienari, J., Piekkari, R. and Säntti, R. (2005). 'Language and the circuits of power in a merging multinational corporation, Journal of Management Studies, 42, 595-623.

van Dijk, H., van Engen, M. L. and van Knippenberg, D. (2012). 'Defying conventional wisdom: a meta-analytical examination of the differences between demographic and job-related diversity relationships with performance'. Organizational Behaviour and Human Decision Processes, 119, 38-53.

van Knippenberg, D. and Schippers, M. C. (2007). 'Work group diversity'. Annual Review of Psychology, 58, 515-41.

Welch, C. and Piekkari, R. (2006). 'Crossing language boundaries: qualitative interviewing in international business'. Management International Review, 46, 417-37.

Welch, D. E. and Welch, L. S. (2008). 'The importance of language in international knowledge transfer'. Management International Review, 48, 339-60.

Xian, H. (2008). 'Lost in translation? Language, culture and the roles of translator in cross-cultural management research'. Qualitative Research in Organizations and Management: An International Journal, 3, 231-45.

Yin, R. K. (2009). Case Study Research: Design and Methods. London: Sage. 


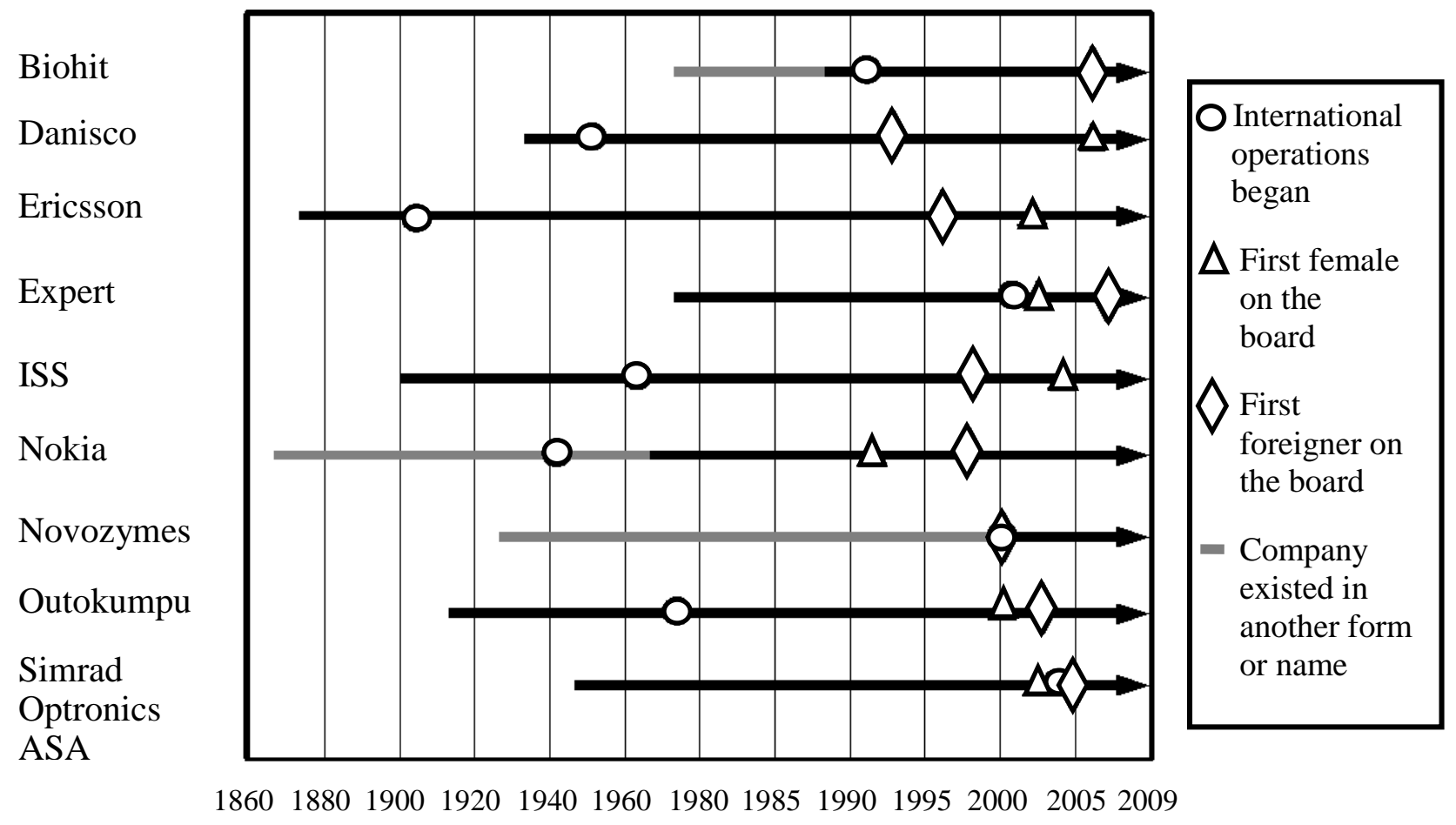

Figure 1. Board internationalization and its relationship with the commercial internationalization of the case companies 


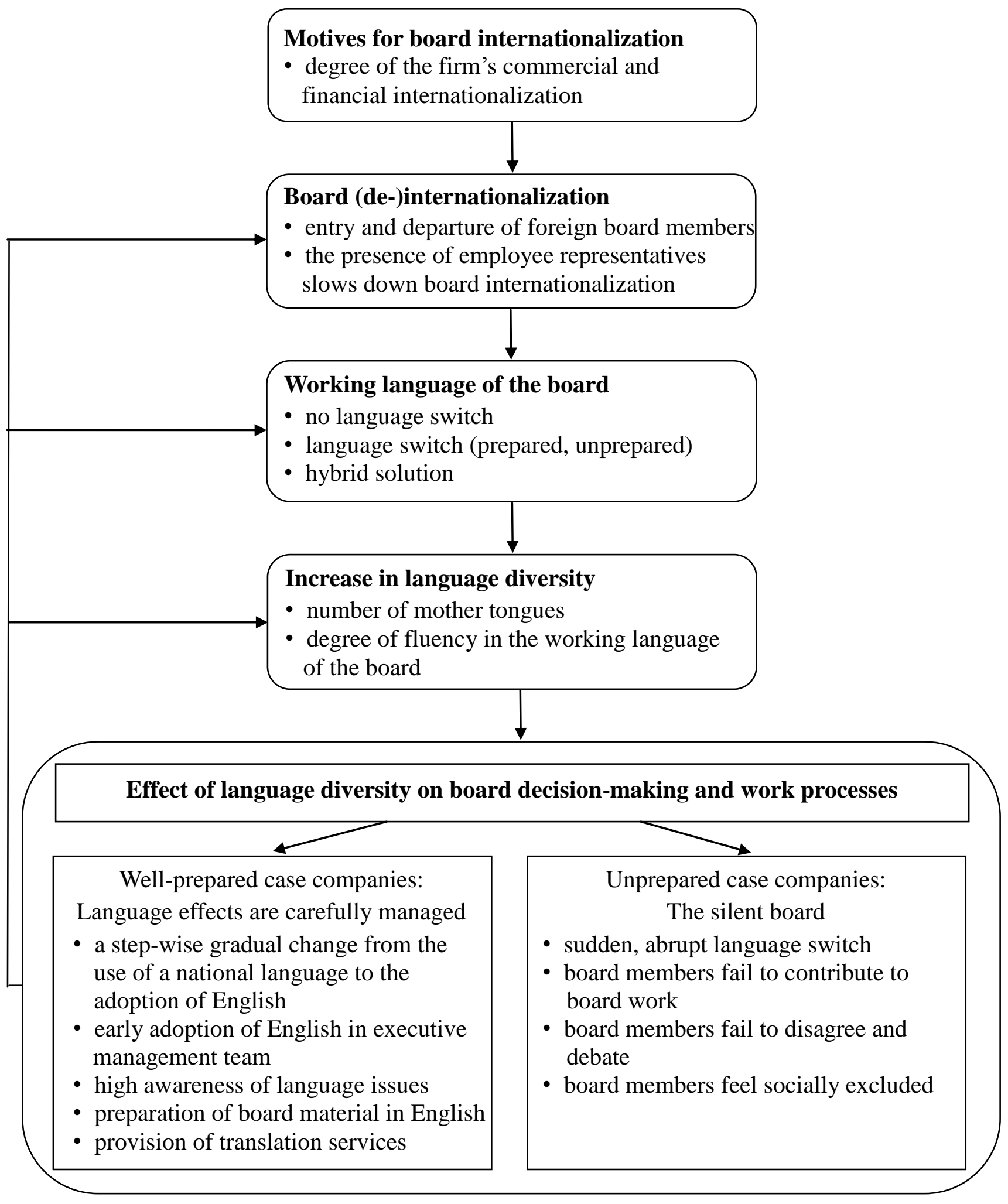

Figure 2. The effect of language diversity on board decision-making and work processes 
Table I. Percentage of foreigners on boards (unbalanced sample)

\begin{tabular}{lccccccc}
\hline \hline & 2001 & 2002 & 2003 & 2004 & 2005 & 2006 & 2007 \\
\hline & & & & & & & \\
DENMARK & 6.52 & 6.00 & 6.09 & 7.00 & 8.59 & 9.64 & 9.50 \\
FINLAND & 7.40 & 8.38 & 7.90 & 9.40 & 9.30 & 11.56 & 13.70 \\
NORWAY & 10.63 & 8.50 & 9.33 & 10.76 & 13.53 & 14.58 & 13.94 \\
SWEDEN & 7.15 & 6.99 & 8.09 & 9.14 & 9.14 & 9.02 & 9.90 \\
\hline \hline
\end{tabular}


Table II. Case selection criteria in 2007

Criteria

Internationalization of board

At least two members of the board being foreign

No

Yes

Criterion 1: Internationlization of sales

High $>50 \%$

$2\left\{\begin{array}{l}\text { Outokumpu } \\ \text { Biohit }\end{array}\right.$

$1\left\{\begin{array}{l}\text { Nokia } \\ \text { Ericsson } \\ \text { ISS }^{\mathrm{a}} \\ \text { Novozymes } \\ \text { Danisco }\end{array}\right.$

Low $<50 \% \quad$ Expert $^{\mathrm{b}}$

Simrad $^{c}$

Criterion 2: Internationalization of

No

$3 \begin{cases}\text { Expert } & \text { ISS }^{\mathrm{d}} \\ \text { Simrad } & \text { Danisco }\end{cases}$

stock exchange

Biohit

Outokumpu

Novozymes

Yes

Nokia

Ericsson

1) Well-prepared case companies 2) Unprepared case companies 3) Outliers

${ }^{\text {a }}$ Before being delisted in 2005

${ }^{\mathrm{b}}$ Close to $50 \%$ foreign sales

${ }^{\mathrm{c}}$ Close to $50 \%$ foreign sales

${ }^{\mathrm{d}}$ Before being delisted in 2005 
Table III: Overview of the personal interviews with board members and executives

\begin{tabular}{|c|c|c|c|c|c|c|c|c|}
\hline & & $\begin{array}{l}\text { \# of } \\
\text { interviews }\end{array}$ & Female & Male & $\begin{array}{l}\text { Current board } \\
\text { members }\end{array}$ & $\begin{array}{l}\text { Former board } \\
\text { members }\end{array}$ & Foreign & Native \\
\hline \multirow{4}{*}{$\begin{array}{l}\text { Biohit, } \\
\text { Finland }\end{array}$} & Chairperson & 1 & & 1 & 1 & & & 1 \\
\hline & Board members & 2 & & 2 & & 2 & 1 & 1 \\
\hline & CEO & 1 & & 1 & 1 & & & 1 \\
\hline & Total & 4 & & 4 & 2 & 2 & 1 & 3 \\
\hline \multirow[t]{2}{*}{$\begin{array}{l}\text { Danisco, } \\
\text { Denmark }\end{array}$} & $\begin{array}{l}\text { Chairperson } \\
\text { Board members } \\
\text { CEO }\end{array}$ & 1 & & 1 & 1 & & & 1 \\
\hline & Total & 1 & & 1 & 1 & & & 1 \\
\hline \multirow{4}{*}{$\begin{array}{l}\text { Ericsson, } \\
\text { Sweden }\end{array}$} & Chairperson & 1 & & 1 & 1 & & & 1 \\
\hline & Board members & 2 & 1 & 1 & 2 & & 2 & \\
\hline & CEO & 1 & & 1 & 1 & & & 1 \\
\hline & Total & 4 & 1 & 3 & 4 & & 2 & 2 \\
\hline \multirow[t]{3}{*}{$\begin{array}{l}\text { Expert, } \\
\text { Norway }\end{array}$} & $\begin{array}{l}\text { Chairperson } \\
\text { Board members }\end{array}$ & 1 & & 1 & 1 & & & 1 \\
\hline & CEO & 1 & & 1 & 1 & & & 1 \\
\hline & Total & 2 & & 2 & 2 & & & 2 \\
\hline \multirow{3}{*}{$\begin{array}{l}\text { ISS, } \\
\text { Denmark }\end{array}$} & Chairperson & 1 & & 1 & 1 & & 1 & \\
\hline & $\begin{array}{l}\text { Board members } \\
\text { CEO }\end{array}$ & 1 & & 1 & 1 & & 1 & \\
\hline & Total & 2 & & 2 & 2 & & 2 & \\
\hline \multirow[t]{3}{*}{$\begin{array}{l}\text { Nokia, } \\
\text { Finland }\end{array}$} & $\begin{array}{l}\text { Chairperson } \\
\text { Board members }\end{array}$ & 1 & & 1 & 1 & & & 1 \\
\hline & CEO & 1 & & 1 & 1 & & & 1 \\
\hline & & & & 54 & & & & \\
\hline
\end{tabular}




\begin{tabular}{|c|c|c|c|c|c|c|c|c|}
\hline & Total & 2 & & 2 & 2 & & & 2 \\
\hline $\begin{array}{l}\text { Novozymes, } \\
\text { Denmark }\end{array}$ & $\begin{array}{l}\text { Chairperson } \\
\text { Board members } \\
\text { CEO } \\
\text { Total }\end{array}$ & $\begin{array}{l}1 \\
3 \\
1 \\
5\end{array}$ & & $\begin{array}{l}1 \\
3 \\
1 \\
5\end{array}$ & $\begin{array}{l}1 \\
3 \\
1 \\
5\end{array}$ & & $\begin{array}{l}2 \\
2\end{array}$ & $\begin{array}{l}1 \\
1 \\
1 \\
3\end{array}$ \\
\hline $\begin{array}{l}\text { Outukumpu, } \\
\text { Finland }\end{array}$ & $\begin{array}{l}\text { Chairperson } \\
\text { Board members } \\
\text { CEO } \\
\text { Total }\end{array}$ & $\begin{array}{l}1 \\
7 \\
1 \\
9\end{array}$ & 4 & $\begin{array}{l}1 \\
3 \\
1 \\
5\end{array}$ & $\begin{array}{l}1 \\
6 \\
7\end{array}$ & $\begin{array}{l}1 \\
1 \\
2\end{array}$ & $\begin{array}{l}3 \\
3\end{array}$ & $\begin{array}{l}1 \\
4 \\
1 \\
6\end{array}$ \\
\hline $\begin{array}{l}\text { Simrad Optronics, } \\
\text { Norway }\end{array}$ & $\begin{array}{l}\text { Chairperson } \\
\text { Board members } \\
\text { CEO } \\
\text { Total }\end{array}$ & $\begin{array}{l}1 \\
1 \\
2\end{array}$ & & $\begin{array}{l}1 \\
1 \\
2\end{array}$ & $\begin{array}{l}1 \\
1 \\
2\end{array}$ & & & $\begin{array}{l}1 \\
1 \\
2\end{array}$ \\
\hline TOTAL & & 30 & 5 & 25 & 26 & 4 & 10 & 20 \\
\hline
\end{tabular}


Table IV: Board composition of the case companies in 2007

\begin{tabular}{|c|c|c|c|c|c|c|}
\hline & $\begin{array}{l}\text { No. of board } \\
\text { members, incl. } \\
\text { employee repr. }\end{array}$ & $\begin{array}{l}\text { No. of } \\
\text { employee } \\
\text { representatives }\end{array}$ & $\begin{array}{l}\text { No. of foreign } \\
\text { board members }\end{array}$ & $\begin{array}{l}\text { No. of female } \\
\text { board members }\end{array}$ & $\begin{array}{l}\text { First foreign } \\
\text { operation/FDI }\end{array}$ & $\begin{array}{l}\text { First foreign } \\
\text { board member }\end{array}$ \\
\hline $\begin{array}{l}\text { Biohit, } \\
\text { Finland }\end{array}$ & 6 & 0 & 1 & 0 & 1991 & 2006 \\
\hline $\begin{array}{l}\text { Ericsson, } \\
\text { Sweden }\end{array}$ & 13 & 3 & 3 & 4 & 1903 & 1996 \\
\hline $\begin{array}{l}\text { Expert, } \\
\text { Norway }\end{array}$ & 8 & 3 & 1 & 2 & 2001 & 2007 \\
\hline $\begin{array}{l}\text { ISS, } \\
\text { Denmark }\end{array}$ & 10 & 3 & 5 & 0 & 1962 & 1998 \\
\hline $\begin{array}{l}\text { Novozymes, } \\
\text { Denmark }\end{array}$ & 10 & 3 & 3 & 1 & 2000 & 2000 \\
\hline $\begin{array}{l}\text { Outokumpu, } \\
\text { Finland }\end{array}$ & 8 & 1 & 3 & 3 & 1975 & 2000 \\
\hline $\begin{array}{l}\text { Simrad Optronics, } \\
\text { Norway }\end{array}$ & 6 & 2 & 1 & 3 & 2004 & 2005 \\
\hline
\end{tabular}


Table V: Language diversity in the boards and executive management teams of the nine case companies in 2007

\begin{tabular}{|c|c|c|c|c|c|}
\hline $\begin{array}{l}\text { Biohit, } \\
\text { Finland }\end{array}$ & English & $\begin{array}{l}4 \text { Finnish, } 1 \text { English, } \\
1 \text { Swedish }\end{array}$ & Medium & Finnish & Nordic only \\
\hline $\begin{array}{l}\text { Danisco, } \\
\text { Denmark }\end{array}$ & English & $\begin{array}{l}7 \text { Danish, } 1 \text { Finnish, } \\
1 \text { Swedish }\end{array}$ & Short & English & Non-Nordic \\
\hline $\begin{array}{l}\text { Ericsson, } \\
\text { Sweden }\end{array}$ & English & 10 Swedish, 3 English & Short & English & Non-Nordic \\
\hline $\begin{array}{l}\text { Expert, } \\
\text { Norway }\end{array}$ & $\begin{array}{l}\text { Hybrid } \\
\text { "Scandinavian" }\end{array}$ & 7 Norwegian, 1 Swedish & Short $^{9}$ & Norwegian & Nordic only \\
\hline $\begin{array}{l}\text { ISS, } \\
\text { Denmark }\end{array}$ & English & $\begin{array}{l}5 \text { Danish, } 3 \text { English, } \\
1 \text { Hindi/English, } 1 \\
\text { Swedish }\end{array}$ & Medium & English & Non-Nordic \\
\hline $\begin{array}{l}\text { Novozymes, } \\
\text { Denmark }\end{array}$ & $\begin{array}{l}\text { Primarily } \\
\text { Danish }\end{array}$ & $\begin{array}{l}7 \text { Danish, } 2 \text { Swedish, } \\
1 \text { Norwegian }\end{array}$ & Short & English & Non-Nordic \\
\hline $\begin{array}{l}\text { Outokumpu, } \\
\text { Finland }\end{array}$ & English & $\begin{array}{l}4 \text { Finnish, } 2 \text { Swedish, } \\
1 \text { French, } 1 \text { Dutch }\end{array}$ & Medium & English & Non-Nordic \\
\hline $\begin{array}{l}\text { Simrad } \\
\text { Optronics, } \\
\text { Norway }\end{array}$ & $\begin{array}{l}\text { Hybrid } \\
\text { Primarily } \\
\text { Norwegian }\end{array}$ & 5 Norwegian, 1 English & Short & English & Non-Nordic \\
\hline
\end{tabular}

\footnotetext{
${ }^{9}$ Because Expert's board uses "Scandinavian", a mixture of Scandinavian languages which allows each member to converse in his or her own mother, instead of English, the distance is measured between Norwegian and Swedish.

${ }^{2}$ Language distance is measured according to Chiswick and Miller (2005).
} 
